\title{
Analisis Strategi Bauran Promosi terhadap Volume Penjualan Restoran XYZ
}

\author{
Analysis of Promotion Mix Strategy on Sales Volume Resturant XYZ
}

\author{
Megalia $^{1}$, Ujang Sumarwan'2, Imam Teguh Saptono ${ }^{3}$
}

${ }^{1}$ Mahasiswa Program Manajemen dan Bisnis, Sekolah Bisnis Institut Pertanian Bogor

${ }^{2}$ Departemen Ilmu Keluarga dan Konsumen, Fakultas Ekologi Manusia Institut Pertanian Bogor

${ }^{3}$ Departemen Agribisnis, Fakultas Ekonomi dan Manajemen Institut Pertanian Bogor

Jl. Raya Pajajaran Bogor 16151

\begin{abstract}
ABSTRAK
Penelitian ini mengkaji pengaruh strategi bauran promosi terhadap volume penjualan dan mengetahui apakah bauran pemasaran yang dijalankan oleh Restoran XYZ memengaruhi pengeluaran konsumen. Teori yang digunakan dalam penelitian ini adalah bauran promosi. Desain penelitian ini dilakukan dengan pendekatan deskriptif kuantitatif melalui wawancara yang menggunakan kuesioner. Metode pengambilan contoh yang digunakan adalah tehnik purposive sampling dengan jumlah responden sebanyak 200 orang. Dalam penelitian ini mengukur pengaruh yang ditimbulkan oleh variabel bauran promosi seperti periklanan, personal selling, promosi penjualan, hubungan masyarakat, dan direct selling terhadap peningkatan volume penjualan. Metode analisis yang digunakan dalam penelitian ini adalah regresi linear berganda. Hasil penelitian menunjukkan bahwa variabel periklanan merupakan variabel yang paling berpengaruh terhadap volume penjualan dan bauran promosi secara bersama-sama memengaruhi keputusan pembelian konsumen. Temuan penelitian ini memberikan implikasi manajerial bahwa restoran XYZ sebaiknya tidak hanya memfokuskan biaya promosi untuk periklanan saja, tetapi juga perlu memperhatikan alokasi dana yang tepat untuk melihat tingkat keefektifan pada peningkatan volume penjualan.
\end{abstract}

Kata kunci: bauran pemasaran, bauran promosi, volume penjualan

\section{ABSTRACT}

This study examines the strategic influence of promotion mix on the volume of aggregation and to know whether the marketing mix run by the Restaurant XYZ affect consumer spending. The theory used in this research is the promotion mix. The research design was conduced with a quantitative descriptive approach through an interview using quisionaire. Sampling method used is a purposive sampling technique with the number of respondents counted 200 people. In this study measure the influence caused by the promotion mix variables such as advertising, personal selling, sales promotion, public relations, and direct selling to increase sales volume. The results show that advertising variables are the most influential variabel of sales volume and the promotion mix simultaneously influences the buying decision of the customer. The findings of this research provide managerial implications that restaurant should not only focus on promotions costs for advertising alone, but also need to pay close attention to the allocation of appropriate funds to see the effectiveness of increased sales volume.

Key words: marketing mix, promotion mix, sales volume

\section{PENDAHULUAN}

Indonesia dikenal sebagai surga kuliner di mata dunia. Rumah makan maupun restoran memiliki peluang yang baik guna memenuhi kebutuhan penduduk akan makanan yang terus meningkat di Indonesia. Bisnis rumah makan maupun restoran terus berkembang dan bertambah setiap tahunnya di Indonesia, seperti yang terjadi di Jakarta. Berdasarkan sumber dari Badan Pusat Statistik mengenai restoran atau rumah makan, jumlah Industri kuliner di Jakarta

\footnotetext{
Korespondensi:

Pondok Jaya no.82 Pondok Aren Tangerang; email: ms.megalia@ymail.com
} 
berjumlah sebanyak 1361 restoran di tahun 2011 dan terus meningkat setiap tahunnya.

Berkembangnya bisnis dibidang kuliner menyebabkan terjadi persaingan diantara pebisnis kuliner. Peluang dan persaingan dalam bidang restoran juga terjadi di kota Jakarta, konsumen yang awalnya tidak terlalu kritis, dimana harga dan rasa menjadi patokan kini berubah, konsumen berubah menjadi sangat selektif dan kritis dalam menentukan pilihan pembelian. Setiap rumah makan atau restoran akan berusaha menawarkan pelayanan yang terbaik kepada konsumennya mulai dari rasa makanan yang unik, tempat yang nyaman, keunikan tempat, service yang memuaskan hingga penawaran harga yang kompetitif.

Semakin ketatnya persaingan yang ada di dunia usaha bisnis kuliner berdampak pada upaya-upaya strategis yang harus dilakukan oleh perusahaan. Strategi perusahaan ini untuk mengantisipasi segala hambatan dan kesempatan yang ada. Untuk tetap bertahan dan meningkatkan volume penjualan, maka perlu dilakukannya strategi pemasaran yang salah satu aspeknya adalah melalui bauran promosi. Walaupun Restoran XYZ memiliki makanan yang enak di sertai dengan harga kompetitif, tetapi banyak muncul pesaing baru lainnya yang menjadi pesaing dari Restoran XYZ. Untuk tetap bertahan dan meningkatkan volume penjualan, perlu dilakukannya strategi pemasaran yang salah satu aspeknya adalah melalui bauran promosi. Bauran promosi yang merupakan salah satu strategi pemasaran sangat dibutuhkan oleh perusahaan dalam upaya untuk meningkatkan daya saing perusahaan. Strategi ini bertujuan untuk meningkatkan volume penjualan dalam sebuah perusahaan (Utari, 2011). Strategi bauran promosi merupakan sarana organisasi yang digunakan untuk mencapai tujuannya dapat diartikan sebagai program umum dari tindakan dan komitmen atas pemahaman dan penempatan produk ke arah pencapaian tujuan menyeluruh berdasarkan kekuatan internal dan peluang yang ada (Setyaningsih, 2007).

Dengan melihat kondisi pasar dan persaingan di industri kuliner, Restoran XYZ terus berusaha untuk melakukan pemasaran yang intensif agar dapat menciptakan permintaan untuk produk restoran tersebut. Dari hasil usaha yang telah dijalankan selama ini volume penjualan dari produk yang dijual oleh restoran mengalami peningkatan. Hal ini dapat dilihat dari tahun 2011-2016 persentase volume penjualan mengalami peningkatan, tetapi pada tahun 2013 ke tahun 2014 mengalami penurunan sebesar $6,03 \%$. Hal ini tidak berpengaruh banyak pada perusahaan karena pada tahun berikutnya penjualan meningkat kembali sebesar 4,53\%, walaupun belum memenuhi target untuk menutupi penurunan yang terjadi pada tahun sebelumnya. Peningkatan volume penjualan periode 2011-2016 yang mengalami peningkatan signifikan terjadi pada tahun 2016 yakni sebesar $27,57 \%$, walaupun dari tahun sebelumnya kenaikan hanya berkisar sebesar 3,6\%. Dengan melihat kondisi yang ada Restoran XYZ merasa perlu untuk mengoptimal-kan upayanya melalui evaluasi atas strategi bauran pemasaran dan bauran promosi yang telah dilaksanakan selama ini apakah masih efektif atau perlu diadakan perbaikan dan pengembangan untuk langkah selanjutnya.

Berdasarkan hal tersebut maka permasalahan dalam penelitian ini adalah melihat apakah strategi bauran promosi yang dilakukan oleh Restoran XYZ berpengaruh terhadap volume penjualan dan komponen biaya promosi mana yang mempunyai pengaruh lebih besar terhadap volume penjualan. Berdasarkan hal diatas, maka berikut kerangka penelitian pada penelitian ini.

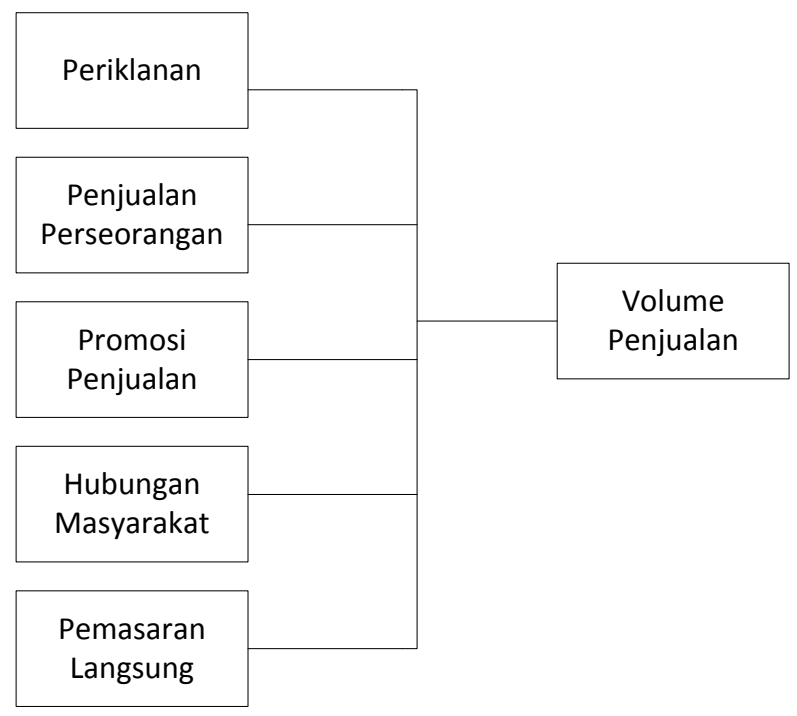

Gambar 1. Kerangka penelitian

Penelitian ini dilakukan untuk mencoba mengkaji permasalahan yang telah dirumuskan. Tujuan penelitian ini adalah untuk mengetahui apakah strategi bauran promosi berpengaruh terhadap volume penjualan restoran $\mathrm{XYZ}$ dan untuk mengetahui apakah komponen biaya promosi memengaruhi pengeluaran konsumen. 


\section{METODE PENELITIAN}

Penelitian ini menganalisis strategi bauran promosi yang digunakan oleh Restoran XYZ dalam meningkatkan volume penjualan dan apakah bauran pemasaran memengaruhi pengeluaran konsumen. Penelitian ini menggunakan parameter biaya-biaya promosi yang digunakan oleh Restoran XYZ dari tahun 2011-2016, serta mengukur seberapa besar komponen dari promosi memberikan kontribusi paling berpengaruh terhadap volume penjualan. Penelitian dilakukan melalui wawancara dan kuesioner di Restoran XYZ. Pengambilan data dilakukan pada tahun 2011-2016. Data yang digunakan adalah data primer dan sekunder. Data primer diperoleh dengan cara observasi di lapangan dan wawancara terstruktur dengan menggunakan alat bantu kuisioner. Data sekunder diperoleh dari studi pustaka, instansi, dan kelembagaan lainnya.

Penelitian ini menggunakan teknik purposive sampling wawancara atau pemberian kuesioner sebanyak 200 diberikan pada saat peneliti bertemu dengan konsumen Restoran XYZ yang dipandang sesuai dengan kriteria sebagai sumber data. Dalam teknik penelitian dengan menggunakan angket yang berisi pernyataan yang sesuai dengan indikator dari setiap masingmasing variabel yang disebarkan secara langsung kepada responden yang telah ditetapkan digunakan instrumen penelitian dengan menggunakan skala. Skala yang diguna-kan dalam angket ini adalah skala likert yang terdiri dari lima opsi jawaban (Tabel 1).

Tabel 1. Skala Likert

\begin{tabular}{lc}
\hline Opsi jawaban & Nilai/ Bobot \\
\hline Sangat Setuju & 5 \\
Setuju & 4 \\
Kurang Setuju & 3 \\
Tidak Setuju & 2 \\
Sangat Tidak Setuju & 1 \\
\hline
\end{tabular}

Bauran promosi meliputi berbagai metode, yaitu Iklan, Promosi Penjualan, Penjualan Tatap Muka dan Hubungan Masyarakat. Bauran promosi menggambarkan berbagai macam cara yang ditempuh perusahaan dalam rangka menjual produk ke konsumen (Sejati et al., 2013).

Bauran promosi memerlukan lebih dari pada sekedar memperkenalkan keunggulankeunggulan produk, dan harga yang menarik, serta membuatnya dapat terjangkau, akan tetapi kegiatan promosi dimaksudkan untuk dapat melakukan komunikasi dengan konsumen, memperkenalkan, membujuk, memengaruhi dan mendorong konsumen untuk membeli produk yang ditawarkan serta dapat juga digunakan untuk membangun citra perusahaan di mata konsumen (Danen et al., 2013). Bauran promosi tidak hanya memperkenalkan keunggulan-keunggulan produk, harga yang menarik, dan membuatnya dapat terjangkau, akan tetapi kegiatan promosi dimaksudkan untuk dapat melakukan komunikasi dengan konsumen, memperkenalkan, membujuk, memengaruhi dan mendorong konsumen untuk membeli produk yang ditawarkan serta dapat juga digunakan untuk membangun citra perusahaan di mata konsumen (Danen et al., 2013).

Dalam penelitian ini terdapat 2 variabel terikat, yaitu volume penjualan dan pengeluaran konsumen. Volume penjualan adalah total dari hasil penjualan yang dicapai oleh Restoran XYZ, sedangkan untuk pengeluaran konsumen adalah, biaya yang dibayarkan konsumen saat kunjungan terakhir ke Restoran XYZ.

Dalam menganalisis data dan menentukan hipotesis penelitian, maka peneliti menggunakan alat analisis Regresi Linear Berganda (Rangkuti, 2008) dengan formulasi sebagai berikut:

$$
\mathrm{Y}=\mathrm{a}+\mathrm{b} 1 \mathrm{X} 1+\mathrm{b} 2 \mathrm{X} 2+\mathrm{b} 3 \mathrm{X} 3+\mathrm{b} 4 \mathrm{X} 4+\mathrm{b} 5 \mathrm{X} 5
$$

Dimana:

$$
\begin{aligned}
& \mathrm{Y}=\text { Variabel terikat } \\
& \mathrm{a}=\text { Konstantan (intercept). } \\
& \mathrm{X}_{1}-\mathrm{X}_{\mathrm{k}}=\text { Variabel bebas } \\
& \mathrm{b}=\text { Koefisien regresi. }
\end{aligned}
$$

Formulasi di atas jika dimasukkan ke dalam variabel penelitian maka dapat diperoleh dua persamaan regresi berganda sebagai berikut: Persamaan 1:

$$
Y=a+b 1 X_{1}+b 2 X_{2}+b 3 X_{3}+b 4 X_{4}+b 5 X_{5}
$$

Dimana:

$\mathrm{Y}=$ Volume penjualan.

$\mathrm{X} 1=$ Periklanan .

$\mathrm{X} 2$ = Penjualan Perseorangan.

X3 = Promosi Penjualan.

X4 = Humas dan Publisitas.

X5 = Pemasaran Langsung.

$\mathrm{a}=$ Konstantan (intercept).

$\mathrm{b}=$ Koefisien Regresi.

Persamaan 2:

$$
Y=a+b 1 X_{1}+b 2 X_{2}+b 3 X_{3}+b 4 X_{4}+b 5 X_{5}
$$

Dimana:

$$
\begin{aligned}
& \mathrm{Y}=\text { Pengeluaran Konsumen } \\
& \mathrm{X} 1 \text { = Periklanan }
\end{aligned}
$$




$$
\begin{aligned}
& X 2=\text { Penjualan Perseorangan } \\
& \text { X3 }=\text { Promosi Penjualan } \\
& \text { X4 }=\text { Humas dan Publisitas } \\
& \text { X5 }=\text { Pemasaran Langsung } \\
& a=\text { Konstantan (intercept) } \\
& b=\text { Koefisien Regresi }
\end{aligned}
$$

Analisis ini digunakan untuk mengetahui ada tidaknya pengaruh secara serempak variabel bebas (biaya promosi) terhadap variable terikat (volume penjualan dan pengeluaran konsumen). Untuk dapat mengukur pengaruh variabel independen terhadap variabel dependen maka perlu dilakukan pengukuran dengan memakai alat analisis statistik. Pemakaian alat analisis statistik diharapkan dapat mengungkap atau mengukur pengaruh variabel independen terhadap variabel dependen secara kuantitatif hingga memudahkan peneliti untuk dapat mengambil kesimpulan secara otentik.

Setelah dilakukan analisis regresi berganda, dilakukan analisis determinasi dan t-test. Analisis determinasi untuk mengetahui seberapa besar variasi volume penjualan Restoran XYZ (variabel terikat) dapat dijelaskan oleh variasi biaya promosi (variable bebas). $\mathrm{D}=\mathrm{r}^{2} .100 \%$

Selanjutnya dari perhitungan regresi tersebut akan diperoleh koefisien determinasi ganda $\left(\mathrm{R}^{2}\right)$ yang digunakan untuk mengukur tingkat ketepatan yang paling baik dari model regresi yang digunakan. Jika $\mathrm{R}^{2}$ yang diperoleh mendekati 1 (satu), maka semakin kuat model tersebut dalam menerangkan variasi faktor independen (bebas) terhadap faktor dependen (terikat). Jika $\mathrm{R}^{2}$ yang diperoleh mendekati 0 (nol), maka semakin lemah model tersebut dalam menerangkan variasi faktor independen (bebas) terhadap faktor dependen (terikat). Secara umum dapat dituliskan bahwa besarnya $\mathrm{R}^{2}$ adalah $0<\mathrm{R}^{2}$ $<1$. Untuk mempermudah mengolah data penelitian ini, penelitian menggunakan program SPSS Release untuk mengolah data statistiknya.

Analisis t-test digunakan untuk menguji nyata tidaknya hubungan antara biaya promosi terhadap volume penjualan.

a. Hipotesis

Ho : $\mathrm{P}=0$ (tidak ada hubungan antara biaya promosi terhadap volume penjualan).

$\mathrm{Hi}: \mathrm{P}=0$ (ada hubungan antara biaya promosi terhadap volume penjualan).

b. Dengan Level of Significant $(\alpha=5 \%$ dengan derajat kebebasan n-2.

Untuk memperoleh $t$ hitung digunakan persamaan menurut Sudjana (1993), yaitu:

\author{
$\mathrm{t}=$ nilai $\mathrm{t}$ hitung \\ $\mathrm{r}=$ korelasi \\ $\mathrm{n}=$ jumlah data \\ Kriteria uji \\ Tolak Ho terima Hi jika $\mathrm{t}$ tes $>\mathrm{t}$ tabel \\ Terima Ho tolak Hi jika $\mathrm{t}$ tes $<\mathrm{t}$ tabel
}

\section{HASIL DAN PEMBAHASAN}

Untuk menggambarkan karakteristik responden Restoran XYZ yaitu para konsumen yang datang ke restoran XYZ. Pertanyaan yang diajukan dalam kuisioner terdiri atas jenis kelamin, pekerjaan, besarnya biaya yang dikeluarkan, dan frekuensi kedatangan bersama siapa.

Karakteristik berdasarkan jenis kelamin terdiri dari $57,5 \%$ pria dan $42,5 \%$ wanita. Secara implikasi bisnis dimungkinkan karena mobilitas dari kaum laki-laki sangat besar karena kebanyakan pengunjung menggunakan Restoran XYZ tidak hanya sebagai tempat makan semata tetapi juga dimungkinkan untuk pertemuan baik pribadi maupun bisnis.

Tanggapan responden mengenai profil pengunjung berdasarkan jenis pekerjaan mayoritas ditempati oleh profesional sebesar 27,5\%, lalu pegawai swasta sebesar $25 \%$, pegawai negeri $20 \%$ dan wiraswasta $17,5 \%$, sedangkan persentase mahasiswa sebagai pengunjung sebesar $10 \%$. Tanggapan responden mengenai profil pengunjung berdasarkan jenis pekerjaan mayoritas ditempati oleh profesional, dan yang terkecil adalah mahasiswa hal ini dikarenakan berdasarkan Restoran XYZ termasuk dalam Restoran untuk kalangan menengah sampai menengah ke atas

Hasil analisis responden berdasarkan pengeluaran pada saat makan di restoran XYZ menjawab rata-rata pengeluaran berkisar Rp4.000.000Rp5.000.000. Hal ini bisa dimungkinkan karena secara harga Restoran XYZ termasuk mempunyai harga yang relatif tinggi, apabila pengunjung restoran berkunjung bersama keluarga atau mengadakan pertemuan bisnis atau jamuan perusahaan hal ini dimungkinkan besarnya pengeluaran pengunjung sedemikian.

Oleh karena variabel bebas yang digunakan dalam penelitian ini lebih dari satu maka alat analisis yang akan digunakan adalah analisis regresi berganda, uji koefisien determinasi $\left(\mathrm{R}^{2}\right)$, dan uji t. 


\section{Analisis Regresi Berganda}

Analisis ini digunakan untuk mengetahui ada tidaknya pengaruh secara serempak variabel bebas (biaya promosi) terhadap variabel terikat (volume penjualan). Penggunaan analisis regresi berganda ini bertujuan untuk membuat model matematis dari bauran promosi terhadap volume penjualan. Volume penjualan akan dijadikan variabel terikat (Y) yang dipengaruhi oleh periklanan (X1), penjualan perseorangan (X2), promosi penjualan (X3), hubungan masyarakat (X4) dan pemasaran langsung (X5) yang menjadi variabel bebas dari regresi bergandanya (Tabel 2).

Hasil persamaan Regresi bauran promosi terhadap volume penjualan:

$\mathrm{Y}=390.414 .788 .045,182+151,824 \mathrm{X} 1-1.204,748$ X2

$+123,162$ X3 + 1.354,338 X4-7.318,700 X5

Keterangan:

$$
\begin{aligned}
& \text { Y = Volume Penjualan } \\
& \text { X1 = Periklanan } \\
& \text { X2 = Penjualan Perseorangan } \\
& \text { X3 = Promosi Penjualan } \\
& \text { X4 = Hubungan Masyarakat } \\
& \text { X5 = Pemasaran Langsung }
\end{aligned}
$$

Dari temuan hasil analisis pada koefisien regresi didapatkan hasil yang berpengaruh paling besar terhadap volume penjualan adalah public relation dengan nilai sebesar 1354,34 (dalam jutaan rupiah), sedangkan periklanan ada pada urutan kedua dengan nilai 151,824 (dalam jutaan rupiah) berdasarkan hal ini restoran dapat mempertimbangkan untuk memaksimalkan penggunaan media promosi Public Relation selain pengalokasian dananya yang tidak terlalu besar, tetapi bisa dimungkinkan penggunaan public relation lebih tepat dan efektif digunakan oleh Restoran XYZ.

Berbeda dengan temuan pada uji $t$ didapatkan hasil media promosi yang paling menonjol adalah periklanan. Hal ini dimungkinkan mengingat alokasi dana untuk periklanan menyedot dana yang paling besar. Dengan membandingkan antara kedua media promosi ini. Fokus promosi perusahaan lebih tepat pada Public Relation dibandingkan pada periklanan, selain dari alokasi dananya yang tidak besar Media Public Relation kemungkinan bisa lebih efektif jika diberdayakan sedemikian rupa pada Restoran XYZ.

Dari koefisien regresi kontribusi pengaruh yang positif dapat diberikan oleh promosi penjualan terhadap volume penjualan. Hal ini dikarenakan program promosi penjualan yang telah dijalankan selama ini masih dapat memberikan peningkatan terhadap nilai volume penjualan sebesar 123,162 (dalam jutaan rupiah).

Kontribusi yang diberikan oleh personal selling -1204,75 dan pemasaran langsung -7318,70 pada persamaan regresi terhadap penjualan mempunyai pengaruh yang negative. Hal ini dikarenakan untuk kedua jenis promosi Restoran XYZ tidak benar-benar fokus dalam menjalankan kedua jenis promosi ini. Untuk kedua jenis promosi Restoran XYZ hanya menjalankan seperti apa adanya yang sudah menjadi keseharian dari tugas seorang pramusaji dan karyawan dalam melayani konsumen, sedangkan yang bertugas sebagai sales person untuk urusan penjualan secara corporate maka manager restoran yang turun langsung menjalankan fungsi tersebut. Pada pemasaran langsung penggunaan media promosi

Tabel 2. Hasil pengolahan

\begin{tabular}{cccccc}
\hline \multirow{2}{*}{ Model } & \multicolumn{2}{c}{ Unstandardized Coefficients } & $\begin{array}{c}\text { Std } \\
\text { Coefficients }\end{array}$ & \multirow{2}{*}{$\mathbf{t}$} & Sig \\
\cline { 2 - 3 } & B & Std E rror & Beta & & \\
\hline $\begin{array}{c}\text { (Constanta) } \\
\text { Periklanan }\end{array}$ & $390.414 .788 .045,18$ & $103.257 .959 .835,36$ & & 3,781 & 0,009 \\
$\begin{array}{c}\text { Penjualan } \\
\text { Perorangan }\end{array}$ & 151,824 & 36,439 & 2,161 & 4,167 & 0,006 \\
$\begin{array}{c}\text { Prom osi } \\
\text { Penjualan }\end{array}$ & $-1.204,75$ & 830,899 & $-0,453$ & $-1,45$ & 0,197 \\
$\begin{array}{c}\text { Public Relation } \\
\text { Pemasaran } \\
\text { Langsung }\end{array}$ & 123,162 & 221,458 & 0,342 & 0,556 & 0,598 \\
\hline
\end{tabular}


masih sangat terbatas pencantuman nama, alamat dan no telpon di directory masih dapat dikatakan kurang efektif sedangkan penayangan berita dan aktivitas restoran pada media online, internet maupun sosmed masih bisa diupayakan untuk efektif.

\section{Analisis Determinasi}

Koefisien determinasi pada intinya mengukur seberapa jauh kemampuan model dalam menerangkan variasi variabel terikat. Nilai koefisien determinasi berkisar dari 0-1 (0\%-100\%). Semakin mendekati nilai 0 maka variabel independen dianggap hanya memiliki pengaruh simultan yang kecil terhadap variabel dependen, sedangkan semakin mendekati nilai 1 maka variabel independen dianggap memiliki pengaruh yang besar terhadap variabel dependen. Hasil dari Uji koefisien determinasi ditunjukan pada Tabel 3.

Tabel 3. Uji Koefisien Determinasi $\left(R^{2}\right)$ Model Summary

\begin{tabular}{|c|c|c|c|c|}
\hline Model & $\mathrm{R}$ & R Square & $\begin{array}{l}\text { Adjusted } \\
\text { R Square }\end{array}$ & $\begin{array}{l}\text { Std. Error of the } \\
\text { Estimate }\end{array}$ \\
\hline 1 & $960 \mathrm{a}$ & 0,921 & 0,856 & $3,09 \mathrm{E}+10$ \\
\hline
\end{tabular}

Berdasarkan Tabel 3, maka dapat dilihat pengaruh bauran promosi yang terdiri dari Periklanan (X1), Promosi Penjualan (X3), Hubungan Masyarakat (X4), dan Pemasaran Langsung (X5) terhadap Volume Penjualan (Y) menghasilkan koefisien korelasi (R) sebesar 0,960. Nilai koefisien determinasi (R2) sebesar 0,921, berarti seluruh variabel bebas dalam hal ini bauran promosi yang terdiri dari periklanan, penjualan perseorangan, promosi penjualan, hubungan masyarakat, dan pemasaran langsung mempunyai kontibusi secara bersama-sama sebesar $92,1 \%$ terhadap variabel terikatnya yakni volume penjualan sebesar $7,9 \%$ dipengaruhi oleh faktor-faktor lain, diluar faktor strategi bauran promosi Restoran XYZ.

\section{Analisis Uji t}

Uji $t$ dilakukan untuk mengetahui pengaruh masing-masing variabel bebas yang terdiri dari periklanan, penjualan perseorangan, promosi penjualan, hubungan masyarakat, dan pemasaran langsung tarhadap variabel terikat, yaitu volume penjualan. Secara parsial pengaruh masingmasing variabel independen tersebut terhadap volume penjualan ditunjukkan pada Tabel 4 .

Berdasarkan hasil kajian analisis uji t di atas bahwa variabel yang paling dominan memengaruhi nilai penjualan adalah variabel periklanan (X1) dengan nilai $t$ hitung yang paling besar $(4,617)$. Dikarenakan pengaruh dari variabel periklanan (X1) yang sangat dominan, maka nampak pada hasil pengujian uji t. Bentuk periklanan yang dilakukan oleh pihak Restoran XYZ seperti Simbol Logo, Iklan cetak, Brosur, Display Sign. Keempat variabel independen yang lain yakni Penjualan Perseorangan (X2), Promosi Penjualan (X3), Hubungan Masyarakat dan Publisitas (Public Relation/Publicity) (X4), dan Pemasaran Langsung (X5), yang tampak mempunyai pengaruh yang kurang signifikan/kecil terhadap peningkatan volume penjualan. Hal tersebut dapat dilihat dari pengalokasian biaya promosi dari variabel periklanan (X1) yang memang mendapatkan pengalokasian biaya promosi yang cukup besar dibandingan ke empat variabel bauran promosi lainnya. Dengan

Tabel 4. Analisis kajian Uji t

\begin{tabular}{|c|c|c|c|c|c|}
\hline \multirow[t]{2}{*}{ Model } & \multicolumn{2}{|c|}{ Uns tandard ized Coefficients } & \multirow{2}{*}{$\begin{array}{c}\text { Std Coefficients } \\
\text { Beta }\end{array}$} & \multirow{2}{*}{$\mathrm{t}$} & \multirow{2}{*}{ Sig } \\
\hline & $B$ & Std Error & & & \\
\hline (Constanta) & $390.414 .788 .045,18$ & $103257.959 .835,36$ & & 3,781 & 0,009 \\
\hline Periklanan & 151,824 & 36,439 & 2,161 & 4,167 & 0,006 \\
\hline $\begin{array}{l}\text { Penjualan } \\
\text { Perorangan }\end{array}$ & $-1.204,75$ & 830,899 & $-0,453$ & $-1,45$ & 0,197 \\
\hline $\begin{array}{l}\text { Promosi } \\
\text { Penjualan }\end{array}$ & 123,162 & 221,458 & 0,342 & 0,556 & 0,598 \\
\hline Public Relation & $1.354,34$ & $1.739,98$ & 1,202 & 0,778 & 0,466 \\
\hline $\begin{array}{c}\text { Pemasaran } \\
\text { Langsung }\end{array}$ & $-7.318,70$ & $2.658,95$ & $-3,159$ & $-2,752$ & 0,033 \\
\hline
\end{tabular}


Tabel 5. Variabel bebas (biaya promosi) dalam juta rupiah

\begin{tabular}{ccrrrr}
\hline Tahun & $\begin{array}{c}\text { Periklanan } \\
(\mathrm{X} 1)\end{array}$ & $\begin{array}{c}\text { Penjualan } \\
\text { Perseorangan } \\
(\mathrm{X} 2)\end{array}$ & $\begin{array}{c}\text { Promosi } \\
\text { Penjualan } \\
(\mathrm{X} 3)\end{array}$ & $\begin{array}{c}\text { Public } \\
\text { relation } \\
(\mathrm{X} 4)\end{array}$ & $\begin{array}{c}\text { Pemasaran } \\
\text { Langsung } \\
(\mathrm{X} 5)\end{array}$ \\
\hline 2011 & 1.855 & 260 & 770 & 341 & 139 \\
2012 & 1.758 & 209 & 708 & 351 & 144 \\
2013 & 1.981 & 210 & 709 & 356 & 146 \\
2014 & 2.932 & 210 & 611 & 374 & 149 \\
2015 & 3.613 & 153 & 353 & 371 & 156 \\
2016 & 4.710 & 137 & 247 & 383 & 168 \\
Jumlah & 16.848 & 1.179 & 3.399 & 2.175 & 902 \\
\hline
\end{tabular}

demikian hipotesis pada penelitian ini yang menyatakan dugaan bahwa variabel periklanan (X1) merupakan variabel yang paling dominan berpengaruh terhadap volume penjualan terbukti dan dapat diterima.

\section{Bauran Promosi}

Menurut Permatasari et al., (2015) dalam penelitiannya mengenai Implementasi Bauran Promosi di Restoran Mahkota, Promosi merupakan salah satu variabel dalam bauran pemasaran yang sangat penting dilaksanakan oleh perusahaan dalam rangka memasarkan produk jasa. Promosi bukan saja sebagai alat komunikasi antara perusahaan dengan konsumen, tetapi juga merupakan alat untuk memengaruhi konsumen dalam kegiatan pembelian atau penggunaan jasa sesuai dengan keinginan dan kebutuhan.

Dari Tabel 5 dapat dilihat bahwa pengeluaran dana untuk promosi yang digunakan pada Restoran XYZ yang paling besar dengan dari tahun 2011-2016 adalah pada periklanan dengan dana sebesar Rp16.848, untuk urutan kedua ada pada promosi penjualan dengan pengeluaran sebesar Rp3.399, yang ketiga pada public relation dengan biaya sebesar Rp2.175, yang keempat ada pada penjualan perseorangan biaya sebesar Rp1.179 dan yang paling terkecil dalam pengeluaran ada pada direct selling (pemasaran langsung) dengan biaya sebesar Rp902. Restoran XYZ mengharapkan dengan biaya promosi yang dikeluarkan diharapkan dapat meningkatkan volume penjualan.

\section{Volume Penjualan}

Dalam dunia usaha suatu perusahaan selalu memerhatikan nilai penjualan yang dicapai dari satu periode ke periode berikutnya. Nilai penjualan secara singkat dapat ditentukan sebagai jumlah produk barang dan jasa yang dihasilkan oleh suatu perusahaan guna memenu-hi kebutuhan konsumen dan dapat disampaikan kepada konsumen melalui proses pertukaran atau jual beli. Dalam usaha untuk meningkatkan penjualan, diperlukan juga usaha promosi. Hal ini dikarenakan promosi yang sesuai dengan rencana pemasaran berarti dapat meningkatkan laju penjualan hasil produksi (Moy, 2015).

Dari Tabel 6 terlihat pendapatan yang diperoleh dari volume penjualan pada tahun 2011 sampai dengan 2016 di restoran XYZ mengalami peningkatan yang signifikan dari tahun ke tahun dengan penjualan tertinggi yang dicapai pada tahun 2016 sebesar Rp682.726.

Tabel 6. Variabel terikat (volume penjualan) 2011 sampai 2016 dalam juta rupiah

\begin{tabular}{ccc}
\hline Talun & Total Volume Penjualan & $\begin{array}{c}\text { Persentase } \\
\text { Kenailan / Penurunan }\end{array}$ \\
\hline 2011 & 283.753 & - \\
2012 & 288.066 & 1,52 \\
2013 & 361.441 & 25,47 \\
2014 & 431.699 & 19,44 \\
2015 & 535.172 & 23,97 \\
2016 & 682.726 & 27,57 \\
\hline
\end{tabular}

\section{Analisis Pengaruh Bauran Promosi Terhadap Volume Penjualan}

Hasil penelitian mengindikasikan bahwa seluruh variabel bebas dalam hal ini bauran promosi yang terdiri dari periklanan, penjualan perseorangam, promosi penjualan, hubungan masyarakat, dan pemasaran langsung mempunyai kontribusi dalam meningkatkan volume penjualan. Dari ke lima variabel bauran promosi, hanya 3 bauran promosi yang memberikan pengaruh positif terhadap volume penjualan, yaitu periklanan, promosi penjualan dan hubungan masyarakat.

Berdasarkan data perusahaan dari Restoran XYZ ini melaksanakan promosi masih dominan pada periklanan yaitu melalui media cetak dan 
media ektronik, sedangkan pada bentuk media promosi lainnya kurang begitu perhatian dan seakan dianggap sebagai pelengkap dari media promosi yang selama ini paling diutamakan digunakan yaitu periklanan, walaupun belum terlihat apakah media promosi yang lain akan lebih bisa mendongkrak volume penjualan setidaknya media promosi yang lain alokasi dananya perlu ditingkatkan juga. Total biaya bauran promosi Restoran XYZ sempat mengalami penurunan pada tahun kedua di tahun 2012 sebesar 5,84\%. Hal ini dikarenakan alokasi dana lebih ditekankan pada pengembangan Restoran $\mathrm{XYZ}$ dalam pembangunan lokasi tempat agar menjadi lebih menarik lagi. Namun, pada tahuntahun berikutnya, total biaya bauran promosi ini terus mengalami kenaikan. Kenaikan terbesar dari total biaya bauran promosi ini terjadi pada tahun 2014, yakni sebesar 25,72\%. Peningkatan secara berkesinambungan dari pengeluaran untuk biaya promosi ini dengan harapan dari perusahaan agar nama dari Restoran XYZ tidak hilang dari ingatan konsumen.

\section{Analisis bauran pemasaran terhadap pengeluaran konsumen}

Pemasaran yang dilakukan oleh pihak perusahaan diharapkan dapat meningkatkan volume penjualan. Menurut Nitisemito (2010) pemasaran merupakan semua kegiatan yang bertujuan untuk memperlancar arus barang dan jasa dari produsen kepada konsumen secara efisien dengan maksud untuk menciptakan permintaan yang efektif. Berdasarkan hal tersebut diharapkan pemasaran yang dilakukan oleh perusahaan dapat memunculkan permintaan yang efektif. Begitu juga dengan restoran XYZ, strategi pemasaran yang dilakukan diharapkan dapat memunculkan permintaan yang efektif, yang pada akhirnya dapat meningkatkan volume penjualan. Pada penelitian ini dari ke enam variabel pemasaran yaitu product, price, place, proof, process dan promotion yang dilakukan oleh Restoran XYZ memengaruhi pengeluaran konsumen secara bersama-sama. Dapat disimpulkan bahwa dari sisi konsumen tidak ada variabel pemasaran yang memiliki pengaruh paling signifikan dari variabel yang lainnya.

\section{Implikasi Manajerial}

Variabel yang paling berpengaruh dan sangat signifikan terhadap volume penjualan adalah periklanan, sedangkan keempat bauran promosi lainnya seperti penjualan perorangan, promosi penjualan, public relation dan direct marketing tidak berpengaruh secara signifikan terhadap volume penjualan. Jika dilihat dari pengalokasian biaya promosi maka variabel periklanan yang memang mendapatkan pengalokasian biaya promosi yang cukup besar dibandingkan keempat variabel bauran promosi lainnya. Berdasarkan hal ini perusahaan sebaiknya mengalokasikan dana untuk biaya promosi bukan hanya terfokus dan paling besar pada periklanan saja, untuk personal selling, promosi penjualan, public relation maupun direct marketing juga perlu mendapatkan alokasi dana yang tepat dengan melihat tingkat keefektivitasannya pada peningkatan volume penjualan. Dari paket promosi yang ditawarkan tersedia menu untuk anak-anak, tetapi pada sosialisasi dan launching ke pasar penekanan pada promosi untuk paket ini kurang gencar dan kurang terdengar gaungnya sehingga banyak konsumen yang kurang paham bahwa restoran ini sebenarnya juga menyediakan paket makanan untuk anak-anak.

\section{KESIMPULAN}

Bentuk strategi promosi yang ada pada Restoran XYZ adalah dengan menggunakan ke 5 (lima) bentuk media promosi yang meliputi; periklanan, penjualan perseorangan, promosi penjualan, hubungan masyarakat, pemasaran langsung. Namun dari penelitian ditemukan alokasi dana terbesar diperuntukkan pada periklanan terutama dengan menggunakan media cetak dan media elektronik seperti iklan cetak, display sign.

Dari hasil analisis untuk melihat pengaruh dari komponen-komponen pemasaran yang berpengaruh terhadap pengeluaran maka dapat disimpulkan bahwa tidak ada komponen dari bauran pemasaran yang sangat dominan bila diuji secara terpisah, tetapi bila secara simultan (bersamaan) maka dapat dikatakan seluruh komponen variabel bauran pemasaran berpengaruh secara signifikan terhadap pengeluaran.

\section{DAFTAR PUSTAKA}

Danen, N., I.P.G. Sukaatmadja, I.W. Budiasa. 2013. Analisis pengaruh biaya promosi terhadap nilai penjualan produk pada UD. Kopi Bali 
Banyuatis, Singaraja. Jurnal Manajemen Agribisnis. 1(1): 1-15

Nitisemito, A. 2010. Marketing. Jakarta(ID): Ghalia Indonesia.

Permatasari, A.L., W. Khistianto, D.E. Julinato. 2015. Impelmentasi bauran promosi pada hotel dan restoran Mahkota Plengkung Banyuwangi. Jurnal Ilmu Administrasi Bisnis.2(1): 1-22.

Rangkuti, F. 2009. Strategi Promosi yang Kreatif dan Analisis Kasus Integrated Marketting Communication. Jakarta(ID): Gramedia Pustaka Utama.
Sejati, B., D.R. Adriansyah, H. Kamilin. 2013. Pengaruh bauran pemasaran terhadap kepuasan konsumen PT. Dua Kelinci Food Industry di Pati Jawa Tengah, Indonesia. Jurnal Management Universitas Islam 45. 1(1): 1-9.

Setyaningsih, Y. 2007. Manajemen strategi bauran pemasaran untuk perusahaan jasa (studi kasus pada AJB Bumiputera) [tesis]. Malang(ID): Universitas Brawijaya.

Utari, W. 2011. Analisis strategi marketing mix PT Combiphar serta pengaruh terhadap peningkatan volume penjualan. Jurnal Mitra Ekonomi dan Manajemen Bisnis. 2(2): 245-258. 